\title{
Influence of lignin content in soybean seed coat on the incidence of the storage fungus Aspergillus flavus $^{1}$
}

\author{
Ísis Barreto Dantas², João Almir de Oliveira², Heloisa Oliveira dos Santos², \\ Édila Vilela Resende Von Pinho², Sttela Dellyzete Veiga Franco da Rosa ${ }^{3 *}$
}

\begin{abstract}
Seed quality may be affected by several factors, including permeability, color, and lignin content in the seed coat. This study aimed at evaluating influence of lignin content in the tegument of seed samples of six different soybean cultivars, in which half of each sample was inoculated with the fungus Aspergillus flavus, on the physical and physiological quality, and on the seed health, during 180 days storage period, under cold chamber with controlled conditions of temperature and RH. For that, at each interval of 60 days, samples were removed, and the physiological quality of these seeds was assessed by means of moisture and lignin contents; and by tests of seed health, germination, and electrical conductivity. The moisture content of seeds remained constant during all storage period. In the seed health test, it was found that inoculation was efficient, once the minimum incidence of the fungus in the inoculated seeds was $85 \%$. In the germination test, there was a trend of reduction on percentage germination with the increase in storage period. However, there was an increase on electrical conductivity of seeds assessed. It was concluded that there is no interference of the lignin content in the seed coat on the resistance to infection by the fungus Aspergillus flavus, even after seed storage for a period of 180 days.
\end{abstract}

Index terms: Glycine max, inoculation, seed storage, resistance to infection.

\section{Influência do teor de lignina no tegumento de semente de soja na incidência do fungo de armazenamento Aspergillus flavus}

RESUMO - A qualidade das sementes pode ser afetada por diversos fatores, entre eles permeabilidade, cor e teor de lignina do tegumento. O objetivo deste trabalho foi avaliar a influência do teor de lignina no tegumento de amostras de sementes de diferentes cultivares de soja, metade de cada uma delas inoculadas com o fungo Aspergillus flavus, na qualidade física, fisiológica e sanitária, durante o armazenamento por um período de 180 dias, em câmara fria. Para isso, a cada período de 60 dias, amostras foram retiradas e a qualidade fisiológica dessas sementes foi avaliada por meio dos teores de umidade e lignina; e pelos testes de sanidade, germinação e condutividade elétrica. $\mathrm{O}$ teor de umidade das sementes permaneceu constante durante todo o período de armazenamento. No teste de sanidade, foi verificado que a inoculação foi eficiente, visto que a incidência mínima do fungo nas sementes inoculadas foi $85 \%$. No teste de germinação, houve tendência de redução da germinação com aumento do período de armazenamento. Entretanto, houve aumento da condutividade elétrica das sementes avaliadas. Conclui-se que não há interferência do teor de lignina no tegumento das sementes na resistência à infecção pelo fungo Aspergillus flavus, mesmo após o armazenamento das sementes por 180 dias.

Termos para indexação: Glycine max, inoculação, armazenamento de sementes, resistência à infecção.

${ }^{1}$ Submitted on 06/07/2011. Accepted for publication on 05/31/2012.

${ }^{2}$ Departamento de Agricultura, UFLA, Caixa Postal 3037, 37200-000-Lavras, MG, Brasil.
${ }^{3}$ EMBRAPA Café, 70770-901-Brasília, DF, Brasil.

*Corresponding author <sttelaveiga@dag.ufla.br> 


\section{Introduction}

Brazil is the second larger soybean worldwide producer. In the 2009/2010 crop season, the area cultivated with soybean in Brazil reached 24.2 million hectares, with a total production of 75 million metric tons (CONAB, 2011). The mean productivity of Brazilian soybean is of 3,106 kg.ha-1; coming to achieve circa 3,190 kg.ha-1 in the State of Mato Grosso, the largest soybean Brazilian producer (CONAB, 2011).

The seed is responsible for transferring to field the technological innovations and the genetic gains resulting from the genetic breeding programs, be them obtained by traditional breeding methods or by genetic engineering. Seed quality, defined as the sum of all the characteristics genetic, physical, physiological, and sanitary of seeds, is one of main factors in determining the success of a crop. Such attributes are largely reflexes of the functions of the soybean seed coat, whose quality may be affected by several factors; and among them should be emphasized the permeability, the color, and the content of lignin (Silva et al., 2008).

The barrier that the seed coat exerts in relation to its behavior, in face of adverse environmental conditions and management practices, occur by the fact that it constitutes a protective layer, i.e., is what limits the direct contact of internal part of seed with the environment, thus protecting the embryo against mechanical injuries and from microorganisms and insects. Besides, the seed coat controls either the gaseous exchanges between the seed and the environment or its imbibition process (Silva et al., 2008).

The lignin is a natural phenolic polymer, which is important for conferring mechanical resistance, to allow the transport of water within the plant, and to propitiate defense to vascular plants. That compound plays a very important role for the physical and physiological quality of soybean seeds. The soybean seed coat is very thin and its lignin content is very low what provides little protection to the radicle, which is situated in very vulnerable region directly below it (Gloria and Camello-Guerreiro, 2006).

Nowadays, the soybean breeding programs aim at selecting soybean genotypes with high contents of lignin in the seed coat, once these seeds will display good resistance to mechanical impacts in relation to cultivars with an impermeable testa (Alvarez et al., 1997). However, it is still not totally clear if correlation exists between lignin content and the thickness of the testa of seed (Gris et al., 2010).

It has to be emphasized, however that the studies aiming at incorporating such characteristic of the seed testa, i.e., the control of water absorption, only aims production of seed with high physiological potential; what, as consequence, would provide more resistance to weathering in the field and less mechanical damages at harvest, as well as a more protracted storage period (Marcos-Filho, 2001).

Among the several processes by which the soybean seeds have to pass until the next crop, the storage plays a very important role, due to Brazilian tropical and subtropical climatic conditions. It is exactly during the storage phase that the largest worries of seed producers assume an essential significance, once it is related to preservation of physiological quality of seeds in the sense of minimizing the speed of the deterioration process.

Many studies report the storage fungi, mainly species Aspergillus sp. and Penicillium sp., as the foremost agents of seed deterioration (Tervet, 1945; Christensen and Kaufmann, 1969; Neergaard, 1979; Dhingra, 1985; Wetzel, 1987). Lorine (2008) reported that circa $10 \%$ of seeds annually produced are lost due to infection by microorganisms, which affect germination and vigor.

Therefore, in this study the objective was to assess the influence of the lignin that is present in the seed coat of different soybean cultivars, on the physical, physiological and sanitary quality of these seeds during storage.

\section{Material and Methods}

The experiment was carried out in the Laboratories of Seed Analysis and Pathology of Federal University of Lavras, municipality of Lavras, State of Minas Gerais, Brazil. The soybean cultivars Silvania RR, Valiosa, Conquista, Celeste, BRS 245, and BRS 247, produced during the 2008/2009 crop season, and with different contents of lignin in their teguments were used for the studies.

The initial physiological quality of seeds (day 0) was determined by assessing: moisture content (oven method at $105^{\circ} \mathrm{C}$ ); germination; and seed sanity, according to standard Rules for Seed Analysis (RSA) (Brasil, 2009). The content of lignin in the seed coat of each cultivar was also assessed by the potassium permanganate method (Van Soest and Wine, 1968).

As previously described, one seed subsample of each cultivar was inoculated with the fungus Aspergillus flavus using the hydric restriction method described by Machado et al. (2001). The PDA culture medium (extract of 200 $\mathrm{g}$ potato; $20 \mathrm{~g}$ dextrose; and $20 \mathrm{~g}$ of Agar), was used for inoculation; into which a mannitol solution was added and adjusted to 1.0 MPa. After autoclaving, $150 \mathrm{~mL}$ of the culture medium containing mannitol were poured into plastic trays measuring $(442 \times 280 \times 75 \mathrm{~mm})$, containing 
as substrate, three sheets of sterile Germitest ${ }^{\circledR}$ paper, previously moistened with distilled water and osmotic potential of -1.0 MPa. To inoculate the substrate into the tray, a scraping was made in a pure culture of the fungus, grown into Petri dishes on common PDA medium, with the aid of a Drigalsky loop, thus obtaining a mixture of conidia mycelia, which was then smeared on top of the substrate. The trays were immediately and aseptically covered with transparent plastic film and placed into an environmental chamber, at $20^{\circ} \mathrm{C}$ and photoperiod of $12 / 12 \mathrm{~h}(\mathrm{~L} / \mathrm{D})$, during five days, for fungus growth. Afterwards, the seeds were evenly distributed on the fungus colony, in a single layer. In addition, a conidia suspension of the fungus, in the concentration of $1 \times 10^{6}$ conidia $\mathrm{mL}^{-1}$ was sprayed over the seeds to ensure their infection.

Subsequent to inoculation, the trays were again placed into the environmental chamber, under conditions identical to the previously described where, in this step, they remained during $48 \mathrm{~h}$. After such period, the seeds were removed from the trays and left to drying under natural environment. Afterwards, these seeds were stored and assessed as previously described. The characteristics assessed were: germination, performed according to Brasil (2009); seed health, by the standard Blotter Test; and electrical conductivity, according to Krzyzanowski et al. (1999).

A completely randomized experimental design was used in the experiment, which was performed with four replications and with treatments arranged in a factorial scheme $6 \times 4 \times 2\{6$ cultivars (Silvania RR, Valiosa, Conquista, Celeste, BRS 245 and BRS 247) x 4 storage periods $(0,60,120$, and 180 days $) \times 2$ conditions of seeds (with and without inoculation)\}. The statistical analyses were performed using the software Sisvar ${ }^{\circledR}$ (Ferreira, 2000) with means for qualitative characteristics compared by Scott-Knott test, at 5\% probability; for the quantitative characteristics, regression analysis was performed.

\section{Results and Discussion}

The result means obtained in the assessment of initial moisture content of soybean seeds with different contents of lignin, subjected or not to artificial inoculation with the fungus Aspergillus flavus and stored until 180 days, were not statistically analyzed and are presented on Table 1. By data therein presented, it can be observed that conspicuous differences in the moisture content means, in function of store period, were not detected; independently of cultivar or artificial inoculation with the fungus Aspergillus flavus.

Table 1. Moisture content (\%) of seeds of six different soybean cultivars, with and without artificial inoculation with the fungus Aspergillus flavus and stored during 0, 60, 120 and 180 days, under controlled conditions of temperature and relative humidity.

\begin{tabular}{crrrrrrrr}
\hline Storage period & \multicolumn{3}{c}{ Day 0 } & \multicolumn{2}{c}{60 days } & \multicolumn{2}{c}{120 days } & \multicolumn{2}{c}{180 days } \\
\hline Cultivar & With & Without & With & Without & With & Without & With & Without \\
\hline Silvania & 9.66 & 9.54 & 8.67 & 8.65 & 9.44 & 9.21 & 9.71 & 9.59 \\
Valiosa & 9.17 & 9.12 & 9.79 & 9.45 & 9.54 & 9.52 & 9.12 & 9.11 \\
Celeste & 9.76 & 9.58 & 10.92 & 10.83 & 9.72 & 9.67 & 10.06 & 10.03 \\
Conquista & 10.56 & 10.22 & 9.20 & 9.12 & 10.05 & 9.98 & 9.87 & 9.86 \\
BRS 245 & 10.78 & 10.76 & 9.33 & 9.23 & 9.18 & 9.17 & 10.43 & 10.39 \\
BRS 247 & 10.68 & 10.5 & 10.55 & 10.46 & 10.56 & 10.41 & 10.07 & 10.02 \\
\hline
\end{tabular}

The differences observed for lignin content on seed coat among the cultivars assessed in the present study were statistically significant (Table 2); as found by Gris et al. (2010) in studies performed with conventional and transgenic (RR) soybean seeds. However, it has not been found statistically significant changes for this parameter after a 180 days storage period (Table 2), as observed by Krzyzanowski et al. (2008) after a storage period of 12 months. Results on lignin content present in the seed coat and in the ranking of cultivars are in agreement with those results previously observed by Alvarez et al. (1997).

The stability of the lignin present in the seed coat, even under storage, may be explained by the insolubility and complexity of the polymer of lignin. Such characteristic makes the lignin a resistant component against degradation caused by majority of microorganisms (Campbell and Sederoff, 1996).

It can be observed that for lignin content (Table 2), the seeds of cultivars Silvania, Valiosa and Conquista 
presented higher values, and were sorted as seeds with high content of lignin; while the seeds of cultivars Celeste,
BRS 247 and BRS 245 presented lower values, and were sorted as seeds with low content of lignin.

Table 2. Percentage content of lignin (g) in the tegument of seeds of six different soybean cultivars, subjected to artificial inoculation with the fungus Aspergillus flavus and stored during periods of 0, 60,120 and 180 days, under controlled conditions of temperature and relative humidity.

\begin{tabular}{ccccc}
\hline & \multicolumn{4}{c}{ Percentage content of lignin $(\mathrm{g})$} \\
\hline $\begin{array}{c}\text { Storage period } \\
\text { (days)/Cultivar }\end{array}$ & Day 0 & 60 days & 120 days & 180 days \\
\hline Silvania & $0.446 \mathrm{aA} *$ & $0.443 \mathrm{aA}^{*}$ & $0.442 \mathrm{aA}$ & $0.442 \mathrm{aA}^{*}$ \\
Valiosa & $0.307 \mathrm{bA}$ & $0.306 \mathrm{bA}$ & $0.306 \mathrm{bA}$ & $0.304 \mathrm{bA}$ \\
Conquista & $0.292 \mathrm{bA}$ & $0.290 \mathrm{bA}$ & $0.290 \mathrm{bA}$ & $0.288 \mathrm{bA}$ \\
BRS 247 & $0.199 \mathrm{cA}$ & $0.196 \mathrm{cA}$ & $0.195 \mathrm{cA}$ & $0.195 \mathrm{cA}$ \\
BRS 245 & $0.192 \mathrm{cA}$ & $0.189 \mathrm{cA}$ & $0.188 \mathrm{cA}$ & $0.188 \mathrm{cA}$ \\
Celeste & $0.176 \mathrm{cA}$ & $0.172 \mathrm{cA}$ & $0.172 \mathrm{cA}$ & $0.171 \mathrm{cA}$ \\
\hline
\end{tabular}

*Means followed by the same small letter in the columns and capital letter in the lines do not statistically differ from each other by the Scott-Knott test, at $5 \%$ probability.

Under conditions in which this study was carried out, the values for lignin content varied between $0.17 \%$ and $0.30 \%$. The lowest values were associated to seeds of cultivars BRS 245 and BRS $247(0.17 \%$ and $0.20 \%$ respectively) and the highest values were linked to seeds of cultivars Silvania and Valiosa $(0.30 \%$ e $0.27 \%$, respectively). Similar values were found by Gris et al. (2010) in study with conventional and genetically modified soybean seeds.

Differences on lignin content in the seed coat of soybean seeds has been observed by several authors (Tavares et al., 1987; Carbonell et al., 1992; Alvarez, 1994; Carbonell and Krzyzanowski, 1995; Panobianco et al., 1999; Menezes et al., 2009). In addition, a large speculation has been raised in relation to lignin content in the soybean plant among the transgenic cultivars (RR) and conventional cultivars (Coghlan, 1999; Gertz-Junior et al., 1999; Kuiper et al., 2001; Edmisten et al., 2006; Nodari and Destro, 2006).

In the test of initial germination, it was observed variation of 11 percentage points on germination percentage; the cultivar Conquista presented the lowest germination percentage (87\%) and the cultivar BRS 245 had the highest germination percentage (98\%) (Table 3). All cultivars were produced at the same local, and under the same edaphoclimatic conditions. Such variation, however, may be explained by the fact that not all cultivars are adapted to the southern region of Minas Gerais state (Southeast Region of Brazil), but to the Southern Region of the country. For electrical conductivity values, it was observed that initially the seeds of all lots presented similar values (between $53 \mu \mathrm{S} . \mathrm{cm}^{-1} \cdot \mathrm{g}^{-1}$ and $63 \mu \mathrm{S} . \mathrm{cm}^{-1} \cdot \mathrm{g}^{-1}$ ), thus suggesting a good initial physiological quality (Table 3 ).

Table 3. Initial physiological quality of seeds of six different soybean cultivars assessed by tests of germination $(\mathrm{G})$ and electrical conductivity (EC).

\begin{tabular}{ccc}
\hline Cultivar & $\mathrm{G}(\%)$ & $\mathrm{EC}\left(\mu \mathrm{S} \cdot \mathrm{cm}^{-1} \cdot \mathrm{g}^{-1}\right)$ \\
\hline Silvania & $89.0 \mathrm{~b}^{*}$ & $63.5 \mathrm{a}^{*}$ \\
Valiosa & $88.0 \mathrm{~b}$ & $58.4 \mathrm{a}$ \\
Conquista & $87.0 \mathrm{~b}$ & $59.1 \mathrm{a}$ \\
BRS 247 & $93.0 \mathrm{a}$ & $52.7 \mathrm{a}$ \\
BRS 245 & $98.0 \mathrm{a}$ & $57.9 \mathrm{a}$ \\
Celeste & $95.0 \mathrm{a}$ & $53.8 \mathrm{a}$ \\
\hline CV $(\%)$ & 4.53 & 9.20 \\
\hline
\end{tabular}

* Means followed by the same letter in the columns do not statistically differ between each other by the Scott-Knott test, at $5 \%$ probability.

By results achieved in the seed health test (Figure 1) it can be verified that artificial inoculation was efficient, once the minimum incidence of the fungus Aspergillus flavus observed in the inoculated seeds was $85 \%$, independent of the cultivar or storage period.

The non-inoculated seed presented low incidence of the fungus Aspergillus flavus, given that after 60 days storage, maximum incidence was observed for the cultivar Silvania, with a mean of only $20.5 \%$; and the minimum incidence was $0 \%$ for the cultivars Conquista, BRS 245, and Celeste, after 180 days storage (Figure 1). 


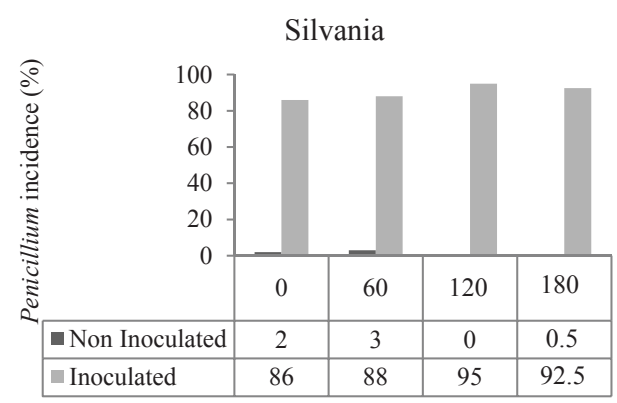

Storage Period (days)

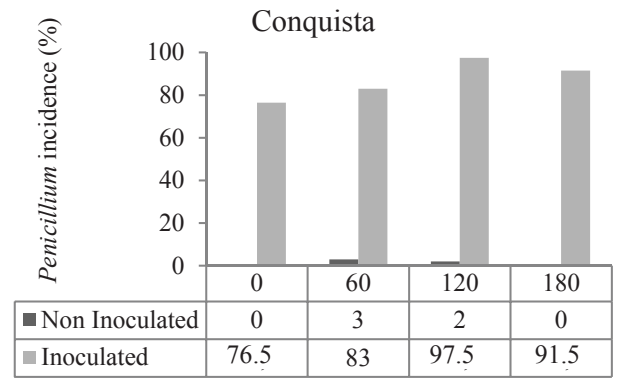

Storage Period (days)

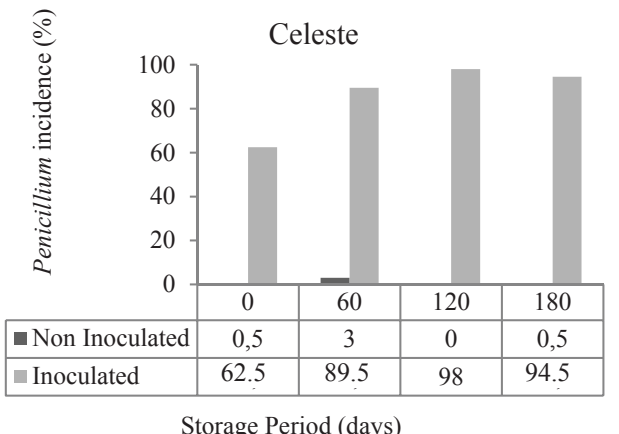

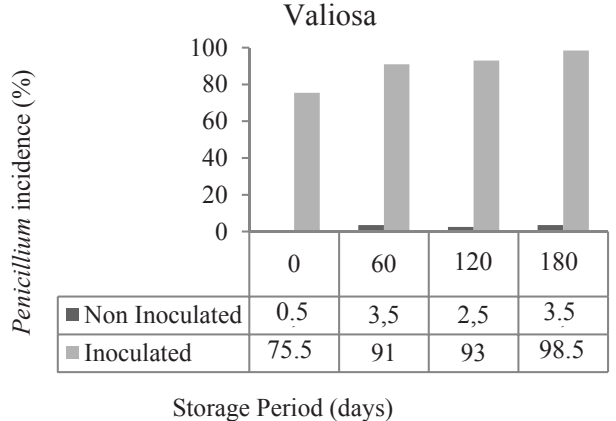

BRS 247

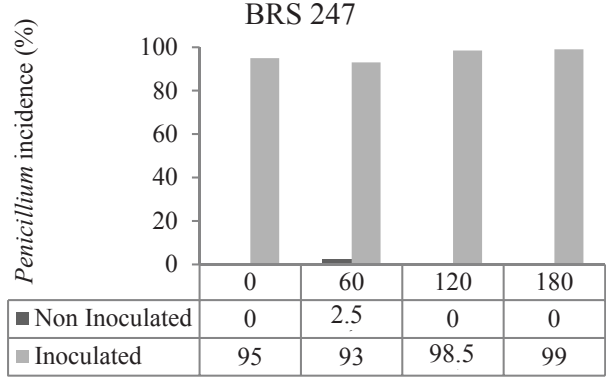

Storage Period (days)

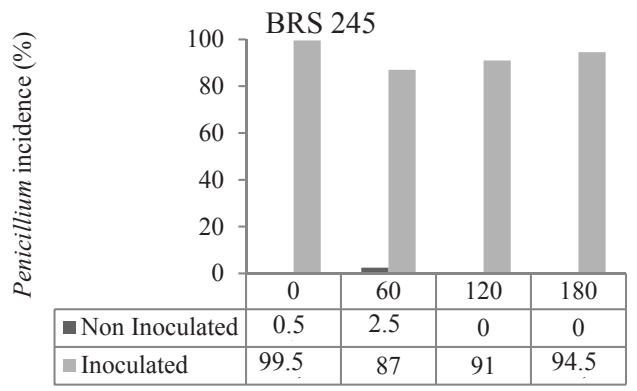

Storage Period (days)

Figure 1. Incidence of the storage fungus Aspergillus flavus in inoculated and non-inoculated seeds of six different soybean cultivars subjected to storage periods of $0,60,120$, and 180 days, under controlled conditions of temperature and relative humidity.

By data of ANOVA (Table 4) it can be verified that there have been significant interactions only for factors: Cultivar $\mathrm{x}$ Storage, for the germination percentage variable; and for factors Fungus incidence x Storage, for the electrical conductivity variable.

A trend of reduction on percentage germination with the increase in storage period was detected for all cultivars assessed; independent if seeds were artificially inoculated or not (Figure 2). It was also found that such decrease was higher for seeds of the cultivar Conquista; which was sorted as having high content of lignin, what is more evident starting from 60 days of storage. Despite the fact that inoculation factor did not influence the interaction of the factors cultivar $\mathrm{x}$ storage (Table 4); the seeds of the cultivars Celeste and BRS 247, with smaller content of lignin in the tegument, were the ones presenting the lowest reduction.

By data shown on Table 5, it becomes evident the higher germination percent for seeds of the cultivars Celeste and BRS 247, whose lignin contents in the seed coat were sorted as the lowest ones.

According to McDougall et al. (1996), the impermeability of the seed coat, conferred by the lignin, exerts significant effect on capacity and speed of water absorption through it; this way interfering in the amount of leachates released from seeds to external environment, during imbibition phase in the germination process.

Crocker (1948) has already mentioned the need for a better knowledge of such mechanism, for considering this as the largest example of efficiency against water 
penetration, and therefore should be better used by plant breeders, by adjusting this characteristic to their needs. As general characteristics of soybean cultivars with less permeable seed coat, it can be cited better potential of preservation, lower levels of infection by pathogens, and higher vigor and viability; besides resistance to moisture absorption after maturation (Panobianco et al., 1999).

Table 4. ANOVA of seeds of six different soybean cultivars with different content of lignin in the tegument, inoculated or not with the storage fungus Aspergillus flavus and stored during 0, 60, 120, and 180 days, under controlled conditions of temperature and relative humidity; and assessed by the tests of germination percent $(\mathrm{G})$, electrical conductivity (EC), and lignin content (LC).

\begin{tabular}{ccccc}
\hline Assessment tests & \multicolumn{2}{c}{ G } & EC & LC \\
\cline { 2 - 5 } Variation Factors & DF & MS & MS & MS \\
\hline Fungus (F) & 1 & $1059.38^{*}$ & $4994.22^{*}$ & $0.3478^{\text {n.s. }}$ \\
Cultivar (C) & 5 & $1073.73^{*}$ & $1007.28^{*}$ & $0.1269^{*}$ \\
Storage (S) & 3 & $2263.29^{*}$ & $22174.98^{*}$ & $0.086^{\text {n.s. }}$ \\
F x C & 5 & $37.98^{\text {n.s. }}$ & $244.70^{\text {n.s }}$ & $0.065^{\text {n.s. }}$ \\
F x S & 3 & $14.68^{\text {n.s. }}$ & $2007.59^{*}$ & $0.052^{\text {n.s. }}$ \\
C x S & 15 & $87.91^{*}$ & $158.20^{\text {n.s }}$ & $0.024^{\text {n.s. }}$ \\
F x C x S & 15 & $23.40^{\text {n.s. }}$ & $133.28^{\text {n.s }}$ & $0.006^{\text {n.s. }}$ \\
\hline Mean & & 85 & 47.39 & 0.26 \\
\hline CV $(\%)$ & & 4.18 & 19.8 & 4.9 \\
\hline
\end{tabular}

n.s. $=$ non-significant, at $5 \%$ probability $*=$ statistically significant, at $5 \%$ probability

Table 5. Germination percentage of seeds of six different soybean cultivars stored during periods of 0,60 , 120 , and 180 days, under controlled conditions of temperature and relative humidity.

\begin{tabular}{ccccc}
\hline \multicolumn{4}{c}{ Germination (\%) } \\
\hline Cultivar & Day 0 & 60 days & 120 days & 180 days \\
\hline Silvania & $90 \mathrm{~b}^{*}$ & $76 \mathrm{c}^{*}$ & $76 \mathrm{c}^{*}$ & $77 \mathrm{~b}^{*}$ \\
Conquista & $93 \mathrm{~b}$ & $80 \mathrm{~b}$ & $76 \mathrm{c}$ & $69 \mathrm{~d}$ \\
Valiosa & $91 \mathrm{~b}$ & $83 \mathrm{~b}$ & $78 \mathrm{c}$ & $79 \mathrm{~b}$ \\
BRS 245 & $96 \mathrm{a}$ & $92 \mathrm{a}$ & $83 \mathrm{~b}$ & $73 \mathrm{c}$ \\
BRS 247 & $98 \mathrm{a}$ & $92 \mathrm{a}$ & $91 \mathrm{a}$ & $86 \mathrm{a}$ \\
Celeste & $99 \mathrm{a}$ & $95 \mathrm{a}$ & $90 \mathrm{a}$ & $87 \mathrm{a}$ \\
\hline
\end{tabular}

*Means followed by the same letter in the columns do not statistically differ between each other by the Scott-Knott test, at $5 \%$ de probability.
As previously mentioned, for the electrical conductivity variable, there has been significant interaction only for the factors Fungus x Storage (Table 4). Data obtained in this study suggest a trend of increased electrical conductivity with the increase of storage period for both: either seeds artificially inoculated or non-inoculated; independent of cultivar (Figure 3).

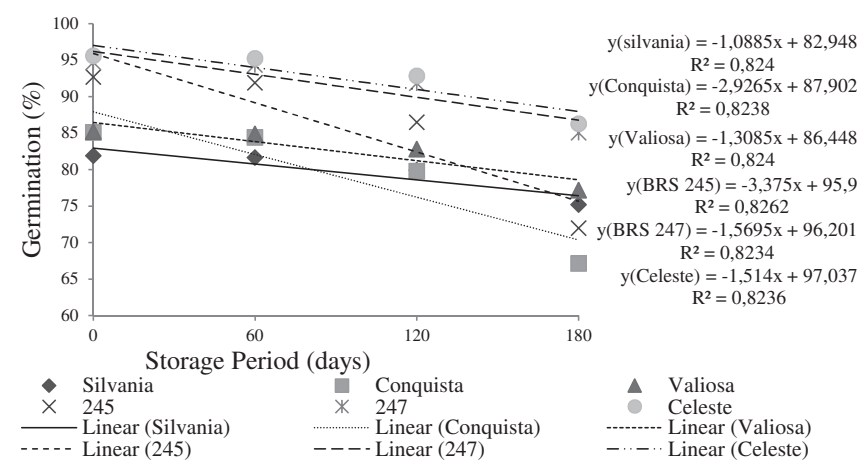

Figure 2. Germination percentage of seeds of six different soybean cultivars, artificially inoculated with the fungus Aspergillus flavus and stored during 0, 60, 120 , and 180 days, under controlled conditions of temperature and relative humidity.

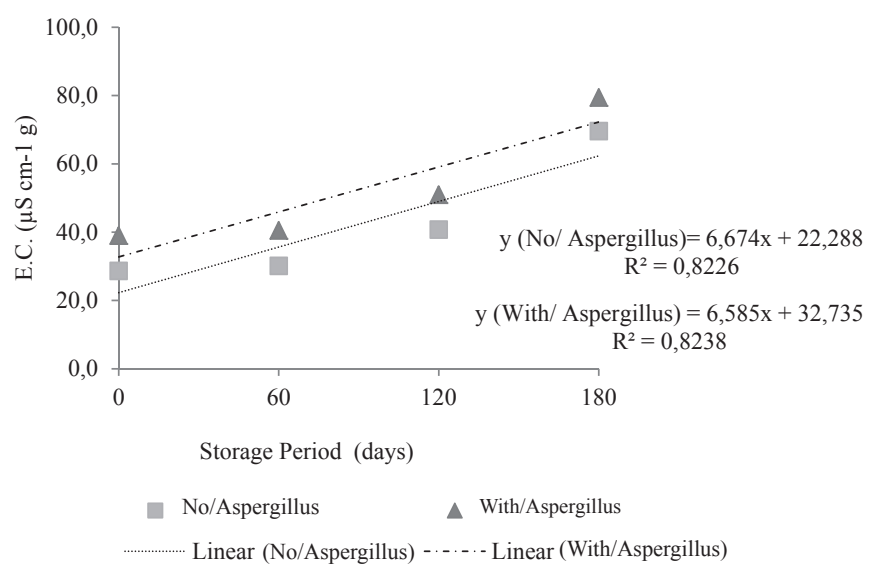

Figure 3. Electrical conductivity (EC) of seeds of six different soybean cultivars, artificially inoculated (With/Aspergillus) or non-inoculated (No/Aspergillus) with the fungus Aspergillus flavus and stored during periods of 0, 60, 120, and 180 days, under controlled conditions of temperature and relative humidity. 
The inoculated seeds had the highest mean incidence of Aspergillus flavus throughout the storage period, when compared with non-inoculates seeds, with differences statistically significant only for storage periods of 60 and 180 days (Table 6). It can also be observed that inoculation with this fungus has led to an increase on electrical conductivity of seeds with the increase of storage period, hence demonstrating that the fungus is able to accelerate the deterioration process, promoted by destruction of the cellular membranes system.

Table 6. Electrical conductivity (EC) of seeds of six different soybean cultivars subjected or not to artificial inoculation with the fungus Aspergillus flavus, and stored under controlled conditions of temperature and relative humidity.

\begin{tabular}{clllc}
\hline \multicolumn{5}{c}{$\mathrm{EC}\left(\mu \mathrm{S} \cdot \mathrm{cm}^{-1} \cdot \mathrm{g}^{-1}\right)$} \\
\hline Seed inoculation & Day 0 & 60 days & 120 days & 180 days \\
\hline Inoculated & $32.81 \mathrm{a}^{*}$ & $53.57 \mathrm{~b}^{*}$ & $58.36 \mathrm{a}^{*}$ & $71.25 \mathrm{~b}^{*}$ \\
Non-inoculated & $22.67 \mathrm{a}$ & $32.17 \mathrm{a}$ & $49.34 \mathrm{a}$ & $59.84 \mathrm{a}$ \\
\hline
\end{tabular}

*Means followed by the same letter in the columns do not statistically differ between each other by the Scott-Knott test, at $5 \%$ de probability.

It was also observed that, even after 180 days storage, the electrical conductivity values found in the inoculated seeds were still considered acceptable for sorting them as seeds with high vigor; although with a strong trend to be sorted as medium vigor seeds. Vieira and Krzyzanowski (1999) have considered as high vigor soybean seeds, those that presented electrical conductivity between $70 \mu \mathrm{S} . \mathrm{cm}^{-1} \cdot \mathrm{g}^{-1}$ and $80 \mu \mathrm{S} . \mathrm{cm}^{-1} \cdot \mathrm{g}^{-1}$. By correlating the variation on seed electrical conductivity of soybean seeds with the content of lignin in the seed coat. Panobianco et al. (1999) have stated that the soybean genotype may change the electrical conductivity in seeds with the same physiological quality standard.

Such observation confirms that has indeed occurred reduction on physiological quality of the seeds assessed; once that the higher their electrical conductivity, the higher will be their deterioration. These data also confirm what was observed in the germination test, where with the increase of storage period there was reduction on germination percent and on the increase of electrical conductivity values, for all cultivars evaluated.

\section{Conclusions}

Soybean seeds with low content of lignin in their tegument have higher potential of germination, even after 180 days storage period, under controlled conditions of temperature and relative humidity.

The lignin content on the tegument of soybean seeds, inoculated or not, with the fungus Aspergillus flavus do not undergo changes during a 180 days storage period, under controlled conditions of temperature and relative humidity.

Higher concentration of lignin content in the tegument of soybean seeds does not confer higher resistance to penetration of storage fungus Aspergillus flavus.

\section{References}

ALVAREZ, P. J. C. Relação entre o conteúdo de lignina no tegumento de soja e sua relação ao dano mecânico. Londrina: FUEL, 1994. 43p.

ALVAREZ, P.J.C.; KRZYZANOWSKI, F.C.; MANDARINO, J. M.; FRANÇA-NETO, J.B. Relationship between soybean seed coat lignin content and resistance to mechanical damage. Seed Science and Technology, v.25, n.2, p.209- 214, 1997.

BRASIL. Ministério da Agricultura, Pecuária e Abastecimento. Regras para análise de sementes. Ministério da Agricultura, Pecuária e Abastecimento. Secretaria de Defesa Agropecuária. Brasília: MAPA/ACS, 2009. 395p. http://www.agricultura.gov.br/arq_editor/file/laborat\%c3\%b3rio/ sementes/regras\%20para \%20analise $\% 20 \mathrm{de} \% 20$ sementes.pdf. Acesso em: 10 fev. 2010.

CAMPBELL, M.M.; SEDEROFF, R.R. Variation in lignin content and composition. Plant Physiology, n.110, p.3-13, 1996.

CARBONELL, S.A.M.; KRZYZANOWSKI, F.C. The pendulum test for screening soybean genotypes for seeds resistance to mechanical damage. Seed Science and Technology, v.23, n.2, p. 31-339, 1995.

CARBONELL, S.A.M.; KRZYZANOWSKI, F.C.; KASTER, M. Avaliação do "teste de queda" para seleção de genótipos de soja com semente resistente ao dano mecânico. Revista Brasileira de Sementes, v.14, n.2, p.215-219, 1992.

CHRISTENSEN, C. M.; KAUFMANN, H. H. Grain storage: the rice of fungi in quality loss. Minneapolis: University of Minnesota, 1969.

COGHLAN, A. Splitting headache: Monsanto's modified soya beans are cracking up in the heat. Saint Louis: Monsanto, 1999. http://www. mindfully.org/ge/monsanto-rr-soy-cracking.htm. Acesso em: 30 mar. 2011.

COMPANHIA NACIONAL DE ABASTECIMENTO. Acompanhamento da safra brasileira: grãos safra 2010/2011. Brasília: Conab, 2011. http:// www.conab.gov.br. Acesso em: 02 fev. 2012. 
CROCKER, W. Growth of plants. New York: Reinohold, 1948.

DHINGRA, O. D. Prejuízos causados por microorganismos durante o armazenamento de sementes. Revista Brasileira de Sementes, v. 7, n. 1, p. $139-145,1985$.

EDMISTEN, K. L.; WELLS, R.; WILCUT, J.W. Investigation of the cavitation and large boll shed in Roundup Ready cotton. Disponível: http://www.cottoninc.com/projectsummaries/2000projectsummaries/ details.asp?projectid=119. Acesso em: 28 mar. 2011.

FERREIRA, D.F. Análises estatísticas por meio do Sisvar para Windows versão 4.0. In: 45a Reunião Anual da Região Brasileira da Sociedade internacional de Biometria. UFSCar, São Carlos, SP, Julho de 2000. p.255258. http://www.dex.ufla.br/ danielff/softwares.htm. Acesso em: 20 jan. 2011.

GERTZ-JUNIOR, J. M.; VENCILL, W.K.; HILL, N.S. Tolerance of transgenic soybean (Glycine max) to heat stress. In: BRIGHTON CROP PROTECTION CONFERENCE: WEEDS, 3., 1999, Brighton. Proceedings... Brighton: BCP, 1999. p.835-840.

GLORIA, B. A.; CARMELLO-GUERREIRO, S. M. Anatomia vegetal. 2. Ed. UFV: Viçosa, 2006. 438p.

GRIS, C. F.; PINHO, E.V. R.; ANDRADE, T.; BALDONI, A.; CARVALHO, M. L. M. Qualidade fisiológica e teor de lignina no tegumento de sementes de soja convencional e transgênica RR submetidas a diferentes épocas de colheita. Ciência e Agrotecnologia, v.34, n.2, p.374-381, 2010. http://www. scielo.br/scielo.php?script=sci_arttext\&pid=s1413-70542010000200015\&lng $=$ en\&nrm=iso. Acesso em: 17 fev. 2012

KRZYZANOWSKI, F.C.; VIEIRA, R.D.; FRANÇA-NETO, J.B. Vigor de sementes: conceitos e testes. Londrina: ABRATES, 1999. 218p.

KRZYZANOWSKI, F.C.; FRANÇA-NETO, J.B.; MANDARINO, J.M.G.; KASTER, M. Evaluation of lignin content of soybean seed coat stored in a controlled enviroment. Revista Brasileira de Sementes, v.30, n.2, p.220223, 2008. http://www.scielo.br/scielo.php?script=sci_arttext\&pid=s010131222008000200028\&lng=en\&nrm=iso. Acesso em: 17 fev. 2012

KUIPER, H.A.; KLETER, G.A.; NOTEBORN, H.P.J.M; KOK, E.J. Assessment of the food safety issues related to genetically modified foods. The Plant Journal, v.27, n.6, p.503-528, 2001.

LORINI, I. Manejo integrado de grãos de cereais armazenados. Passo Fundo: Embrapa Trigo, 2008. 72 p.

MACHADO, J.C.; OLIVEIRA, J.A.; VIEIRA, M.G.G.C. Uso da restrição hídrica na inoculação de fungos em sementes de milho. Revista Brasileira de Sementes, v. 23, n.2, p. 88-94, 2001.
MARCOS-FILHO, J. Pesquisa sobre vigor de sementes de hortaliças. Informativo ABRATES, Londrina, v. 11, n. 3, p.63-75, 2001.

McDOUGALL, G. J. et al. Plant cell walls as dietary fibre: range, structure, processing and function. Journal of Science Food and Agriculture, v. 70, n. 2, p. 133-150, Feb. 1996.

MENEZES, M.; VON PINHO, E.V.R.; JOSE, S. C. B. R.; BALDONI, A.; MENDES, F.F. Aspectos químicos e estruturais da qualidade fisiológica de sementes de soja. Pesquisa Agropecuária Brasileira, v.44, p.1716-1723, 2009.

NEERGAARD, P. Seed pathology. London: Macmillan, vol.1st, Revised Edition, 1979. 229p.

NODARI, R.O.; DESTRO, D. Relatório sobre a situação de lavouras de soja da região de Palmeira das Missões, RS, safra 2001/2002, cultivadas com cultivares convencionais e com cultivares transgênicas. http://www. agirazul.com.br/123/noticias/000000a3.htm. Acesso em: 16 mar. 2011.

PANOBIANCO, M.; VIEIRA, R.D.; KRZYZANOWSKI, F.C.; FRANÇANETO, J.B. Electrical conductivity of soybean seed and correlation with seed coat lignin content. Seed Science and Technology, v.27, n.3, p.945-949, 1999.

SILVA, M. A. D.; VIEIRA, R. D.; SANTOS, J. M. Influência do envelhecimento acelerado na anatomia da testa de sementes de soja, cv. Monsoy 8400. Revista Brasileira de Sementes, v.30, n.2, p.91-99, 2008. http://www.scielo.br/scielo.php?script=sci_arttext\&pid=S010131222008000200012\&lng=en\&nrm=iso. Acesso em: 19 dez. 2011.

TAVARES, D.Q.; MIRANDA, M.A.C; UMINO, C.Y.; DIAS, G.M. Características estruturais do tegumento de sementes permeáveis e impermeáveis de linhagens de soja, Glycine $\max ($ L.) Merrill. Revista Brasileira de Botânica, v.10, n.1, p.147-153, 1987.

TERVET, I. W. The influence of fungi on storage on seed viability and seedling vigor of soybeans. Phytopathology, v. 35, p. 3-15, 1945.

VAN SOEST, P.J.; WINE, R.H. Determination of lignin and cellulose in aciddetergent fiber with permanganate. Journal Association of Agricultural Chemistry, v.51, p.780-785, 1968.

VIEIRA, R. D.; KRZYZANOWSKI, F. C. Teste de condutividade elétrica. In: KRZYZANOWSKI, F. C.; VIEIRA, R. D.; FRANCANETO, J. B. (Ed.). Vigor de sementes: conceitos e testes. Londrina: ABRATES, 1999. cap. 4, p. 1-26.

WETZEL, M. M. V. S. Fungos de armazenamento. In: SOAVE, J.; WETZEL, M. M. V. S. Patologia de sementes. Campinas: Fundação Cargill, 1987. cap. 9, p. 260-275. 